\title{
Article \\ Tourism Workers and Entrepreneurs during the 1950s and 1960s in Sant Antoni de Portmany (Ibiza, Spain)
}

\author{
José Ramón-Cardona ${ }^{1, *(D)}$ and María Dolores Sánchez-Fernández ${ }^{2}$ (D) \\ 1 Ibiza Island Council University College of Tourism, University of the Balearic Islands, 07800 Ibiza, Spain \\ 2 Department of Business, University of A Coruña, 15071 A Coruña, Spain; maria.sanchezf@udc.es \\ * Correspondence: jose.ramon@uib.es; Tel.: +34-971-307-255
}

Citation: Ramón-Cardona, José, and María Dolores Sánchez-Fernández. 2022. Tourism Workers and

Entrepreneurs during the 1950s and 1960s in Sant Antoni de Portmany (Ibiza, Spain). Social Sciences 11: 56 https://doi.org/10.3390/ socsci11020056

Academic Editor: Carlos Teixeira

Received: 29 December 2021

Accepted: 28 January 2022

Published: 29 January 2022

Publisher's Note: MDPI stays neutral with regard to jurisdictional claims in published maps and institutional affiliations.

Copyright: (C) 2022 by the authors. Licensee MDPI, Basel, Switzerland. This article is an open access article distributed under the terms and conditions of the Creative Commons Attribution (CC BY) license (https:// creativecommons.org/licenses/by/ $4.0 /)$.

\begin{abstract}
Ibiza is very dependent on the tourism sector and is a highly recognized international brand. However, before the tourist boom, the situation was different, since it was an economically underdeveloped and almost unknown island. In the 1950s, an eminently endogenous tourism development began thanks to local entrepreneurship, usually workers and modest traders who dared to invest in the new sector. The development was not homogeneous throughout the island, with Sant Antoni de Portmany being the pioneer town in the post-Spanish Civil War recovery (1939-1959), the example from which the rest of the island learned and the starting point of the current image of Ibiza. This article seeks to delve into the social context of Sant Antoni in its tourist beginnings, especially in the mentality and way of being of the workers and businessmen of that time. It is an economic history paper that analyzes bibliography and testimonies of that time to provide a vision of what society, tourism and pioneering entrepreneurs were like. The peculiarities of the society, workers and entrepreneurs from the beginnings of the tourism sector have generated many of the positive and negative elements of current society and tourism in Ibiza, highlighting the survival of a mentality, way of doing and vital approach based on networking, irregularities and improvisation.
\end{abstract}

Keywords: history; businessmen; workers; Ibiza; Sant Antoni de Portmany

\section{Introduction}

The Pityuses islands are a small archipelago formed by two islands, Ibiza $\left(571.79 \mathrm{~km}^{2}\right.$ and 151,827 inhabitants) and Formentera (82.53 $\mathrm{km}^{2}$ and 11,904 inhabitants), and various islets of varying size (Espalmador, Tagomago, Sa Conillera, Es Vedrá, Es Vedranell, etc.). For fifty years, both islands have been highly dependent on the tourism sector (Michaud 2012; Ramón 2001; Ramón and Serra 2014b) and constitute two highly recognized international tourism brands, especially Ibiza (Michaud 2012). Although this has not always been the case and, during the 1950s and 1960s, tourism still did not have the current weight and the island did not have the national and international relevance that it acquired at the end of the 1960s. Several anecdotes from interviewees show the enormous lack of knowledge about Ibiza at that time, even in places like Madrid.

Although both islands share culture, history (Ferrer 2019) and climate, being sun and beach destinations, especially marked by a hippie (Gil 1970, 1971; Michaud 2012; Ramón 2001; Ramón and Serra 2014a; Rozenberg 1990) and freedom past, have evolved towards a duality of symbolic opposites (Azpelicueta et al. 2015; Cirlot 2021): Ibiza recalls stimuli (party, leisure, luxury, etc.), night and human interaction (Berrozpe 2016; Berrozpe et al. 2017; Ramón and Serra 2013b); Formentera is sensations (relaxation, tranquility, meditation, etc.), day, and nature (Ramón 2017c). This opposition of images constitutes complementary tourist products united by a day and night tourist cycle, visualized in the daily movements of the large yachts between the marinas of Ibiza and the beaches of Formentera (visible through websites such as MarineTraffic and VesselFinder).

However, before the tourist boom and the hippie movement (Ramón 2001) the situation was different. Both islands were poor, economically underdeveloped, and almost unknown, 
even within Spain. Furthermore, the situation was very different according to the areas: Formentera, the north of Ibiza and the southernmost coast of Sant Josep, had little tourist development, being the areas preferred by members of the counterculture (Rozenberg 1990); Vila (popular name for the city of Ibiza, capital of the island), Sant Antoni and the beaches closest to these centers concentrated the tourist activity. These differences have translated into important differences in the natural and urban landscape of these areas, especially along the coastline, being much more degraded in Sant Antoni and Vila.

Although foreign visitors have arrived since the 19th century, leaving some testimonies of that time, such as that of Gaston Vuillier (1893), and excursions from the beginning of the 20th century (Ramón 2001), tourism appears as such in the 1930s, just before the Spanish Civil War (Cirer 2004, 2021a, 2021b; Ramón 2001; Ramón and Serra 2014c), and it is when it is possible to speak of a tourist sector in Ibiza (Cirer 2004; Ramón 2001; Ramón and Serra 2014b). Between 1932 and 1935, the first hotels on the island appeared, distributed among the three urban centers of the island (Vila, Sant Antoni and Santa Eulària), although Vila led, having accumulated $60 \%$ of the accommodation places; however, these data today would be considered anecdotal.

From that time there are the testimonies of several foreign intellectuals who resided for some time on the island and published about their experiences: Walter Benjamin in Sant Antoni (Benjamin 2008; Valero 2001, 2004) and Elliot Paul in Santa Eulària (Paul 1937). These authors and the local press are the main sources of information from those years, as there are no living testimonies left today. The interpretation of these sources caused that the vision of the academics in the 1930s in Ibiza was diverse, oscillating between a commercial, entrepreneurial and economic center (Cirer 2021a, 2021b) and a primitive, archaic and almost tribal society (Vives and Rullan 2020); other authors are more balanced and reasonable: "it was an uncultured island, but it was not a wild atoll either" (Rubert 2003, p. 23). Likely, the heterogeneity of situations of that time is the cause of these very opposite views, and also the different theses defended by the authors consulted. There were a few people with university or equivalent education, well-traveled and with sufficient resources to invest in tourism business projects, but also a large illiterate population, or with a very basic literacy, who subsisted on the exploitation of small farms, usually rainfed, and without knowledge or resources to invest and create companies.

The importance of the 1930s is due to the emergence of the tourism sector, but one cannot speak of consolidation as some authors claim (e.g., Cirer 2004), at least in light of the Tourist Area Life Cycle Theory proposed by Richard Butler (1980) and his phase of consolidation of a destination, something that in Ibiza did not occur until the end of the century (Ramón 2017a). To get an idea of the size of the sector in those years, it should be noted that in 1935, 5446 tourists arrived on the island, of which 1205 were foreigners (Ramón 2001). Regarding the offer, there were 14 accommodation establishments with 271 rooms and 473 beds (Cirer 2004; Ramón 2001). To put these figures in context, it should be noted that in 1935 there were approximately 36,000 inhabitants on the island. In the 1930s, some people were strong supporters of tourism, but the majority of the population still considered it an anecdote rather than a potential economic sector.

In 1936 the Spanish Civil War broke out and the national panorama changed completely. Ibiza and Formentera had a less bad situation than other regions of the country, except for several weeks in August and September 1936. During those weeks there were arrests and shootings committed by Republican militiamen, causing a harsh response from the National side when they recovered the islands (Parrón 2000). One of the effects of these changes was the occupation or closure of accommodation establishments, with the exception of those in Sant Antoni (Cirer 2004; Planells 1984; Ramón 2001). The national and international situation did not allow changes until 1946, when some establishments tried to reopen, although with enormous difficulties (Ramón 2001).

After the end of the Second World War, an attempt was made to recover exports from the primary sector, highlighting here potatoes for the United Kingdom together with the traditional sales of almonds and carob beans, and an attempt was also made to recover 
the incipient tourism sector that, in the early 1950s, had the same supply and demand figures as in 1935 (Cirer 2004; Ramón 2001). The Spanish Civil War, the Second World War, the postwar years (from the end of the Spanish Civil War in 1939 to the 1950s) and the international embargo caused fifteen years of delay in the development of the tourism sector. Furthermore, there was no accelerated growth in tourism until the opening of the airport in 1958 (Ramón 2001) and the 1950s were still times of modest data.

In general, the 1940s and 1950s were years of poverty, especially the 1940s. The legal population in the Pityuses was 38,524 inhabitants in 1940 and 37,225 inhabitants in 1960, resulting in a population loss of 3.37\% (INE 2021) that resulted in the emigration of many inhabitants to Latin American countries (Argentina, Venezuela, etc.) and Europe (mainly Germany). These are the only two decades of the 20th century in which the islands lose population and the last period of significant emigration flows. The testimonies of the inhabitants of that time summarize those years with the word "hunger", leaving in them a bitter memory of scarcity and poverty.

The development of tourist packages and charter flights in Europe allowed that from the end of the 1950s the tourist development of Ibiza accelerated, thanks to the opening of the Es Codolar airport, reaching the tourist boom and the countercultural presence of the late 1960s and the early 1970s that generated an important media impact and the first wave of academic studies on society and tourism in Ibiza and Formentera (e.g., Alarco 1978; Cooper 1974; Gil 1970, 1971; Nieto 1977; Robertson 1965; Rozenberg 1974; Takeuchi and Kurihara 1979). This abundance of academic studies died out with the end of the hippie movement and did not appear again until well into the 21st century.

It should be noted that tourism development was irregular, beginning in the town of Sant Antoni in the 1950s. It continued in Vila, extending to coastal areas of the municipality of Sant Josep bordering Sant Antoni (Cala de Bou) and Vila (Platja d'en Bossa) in the 1960s. Santa Eulària delayed its tourist development thanks to the income generated by the potatoes exported to the United Kingdom, the town being the north of the municipality of Santa Eulària, and the island of Formentera the last areas to start tourist development, only in the 1970s. In the 1980s, some more coves were urbanized, such as Cala Tarida in Sant Josep. In the north of Ibiza, the municipality of Sant Joan was left out of tourist development, with the exception of the Sant Miquel port and some isolated hotels, being the only municipality that had a reduction in its population in the 20th century, losing $4.1 \%$, while on the whole, the Pityuses increased by $260.9 \%$.

Of the areas mentioned, the most interesting is Sant Antoni, as it was the first to recover after the Spanish Civil War, the example from which the rest learned and the starting point of the current image of the island. The objective of this article is to delve into the context of Sant Antoni in its beginnings as a tourist destination, especially in the workers and entrepreneurs of that time. It is a paper on economic history that analyzes the existing bibliography and consults testimonies to complete the vision of what society and tourism development were like.

The tourist workers were young people from the countryside who were looking for an improvement in their economic and social conditions. Until 1965, they were mainly from the island, but from that year on, the arrival of workers from outside was necessary. As will be discussed below, the tourism development of Ibiza was eminently endogenous and the entrepreneurs were local workers who decided to start and create a business linked to the tourism sector. This implied deficiencies in many of the companies created that have generated repercussions in subsequent decades.

This article is divided into various sections: a methodology section briefly exposing the sources consulted; a review of the evolution of tourism in Sant Antoni de Portmany during the first decades of sector development; the main part is a review of the mentality and way of being of the tourist workers and entrepreneurs of the 1950s and 1960s in Sant Antoni; and finally there is a section of conclusions where the main implications for the present of the elements discussed in the previous sections are reviewed. The peculiarities of the society, workers and entrepreneurs, differentiating from other societies by its mentality and way 
of doing, from the beginnings of the tourism sector have generated many of the positive elements, highlighting this risky and enterprising mentality, and negative elements, mainly the tendency for irregularities, favor networks and improvisation, elements of the current society and tourism of the island. Although, since it is a case study (Yin 2017) and not a comparison, it is not possible to affirm that Sant Antoni is a unique case. However, it is true that the mentality of the local population surprised external researchers, such as Ronald Cooper (1974), and the use of social movements (e.g., hippies) for tourism development, instead of their expulsion due to social scandal, was not usual, as shown by analyses carried out in the Greek islands (Nikolakakis 2015).

\section{Methodology}

As this paper is a case study (Yin 2017) of economic history, the methodology used in this review focused on the available bibliography and on interviews with people who lived or worked in the town during the years analyzed. The people in these interviews were young (between 15 and 40 years old during that time) and worked in activities related to the tourism sector (e.g., waiters, shopkeepers, tour guides, etc.). As for the bibliography, two types of texts were used: economic history books that analyze the island as a whole and occasionally mention Sant Antoni; and interviews with people of that time, published in the press or compiled in books. The previously published interviews have two virtues compared to other sources: They are testimonies of people of that time who have already died and, therefore, cannot be interviewed today; and, as these are interviews conducted in the past, the responses are less affected by alterations in the memories of the interviewees. It must be borne in mind that with the passage of time people modify their memories (they forget details, reinterpret elements, modify their story to adjust it to current views of the past, etc.) and in these types of interviews these alterations are minor. During recent interviews, several cases of this type of alteration in the story were detected: international relevance of the island; Franco Regime restrictions on various aspects; role of women in tourism development; among others. All of them due to "interferences" of the current political-ideological debate in the memory, or exposure, of the past.

Once the secondary sources were consulted, gaps or inconsistencies appeared in the story, suspected of being due to alterations in the story to adjust it to current ideological views; several businessmen and workers from Sant Antoni who lived through that time were interviewed. These people interviewed were also young during the period studied (now they are over 60 years old and some are over 80 years old), lived in the town or nearby and worked in the tourism sector at that time. These interviews focused on specific details absent in the bibliography, such as the training of entrepreneurs at that time, the behavior of tourist workers or the role of women in the sector. Due to the fact that one of the authors has lived on the island for years, the interviews were not carried out on specific dates, but were carried out when the opportunity arose and in parallel to the bibliographic consultation process that extended over several years. In general, these interviews made it possible to greatly clarify some of the apparent inconsistencies.

The result of both sources of information is set out in the following sections regarding Sant Antoni tourism and tourism workers and businessmen. It is important to know the profile of the workers of that time because most of the entrepreneurs of the first decades of tourism in Ibiza emerged from among them; this being the mentality and the way of doing of the entrepreneurs, and thus the continuation of the mentality and way of doing of the workers.

\section{Origins of Tourism in Sant Antoni de Portmany}

During the first third of the 20th century, the situation of Sant Antoni did not vary from what was commented on for the whole of the island. There is evidence of some visitor arrivals to the bay (for example, a naval maneuver in 1913 or a ship arrived from Denia in 1927) but it was not until the 1930s that the tourism activity itself began. In those years, some foreigners, especially Germans, came to the island and also to Sant 
Antoni (Pizza 2016; Valero 2004). The best-known case is Walter Benjamin, who lived in the town during the summers of 1932 and 1933, leaving testimony of his visit and what he saw (Benjamin 2008; Valero 2001). Based on his testimony, it is known that the two inns that Sant Antoni had (Esmeralda and Miramar) began to have their own rooms in 1933 (Valero 2001). However, the starting point of tourism was with the inauguration of the Portmany Hotel (18 rooms) on 12 July 1933. This hotel was an initiative of José Roselló Cardona, an exceptional person in the town due to his education (agronomist), his financial capacity and knowledge of languages, having traveled and known various European countries. In relation to his private life, it seems that he was also an unconventional person. Based on these trips, he realized the potential of tourism as an economic sector and its ability to develop poor areas such as Sant Antoni (Cirer 2017). José Roselló was personally involved in tourism promotion activities for decades. He was an entrepreneur described by Walter Benjamin as the richest man in the town (Valero 2001). In 1935, other two hotels opened: the San Antonio Hotel (20 rooms) and the Ses Savines Hotel (15 rooms). The Ses Savines Hotel, opened by Rafael Marino Llácer, was the first hotel opened in the bay area, outside the town of Sant Antoni, but very close to the urban center (Cirer 2004; Ramón 2001; Ramón and Serra 2014c). Rafael Marino was the son of a returned emigrant and was already managing the Esmeralda Inn before the opening of the Ses Savines Hotel. In later decades, he and his son expanded this hotel on several occasions and opened the Bahía Hotel.

In 1936, the Civil War stopped everything and only the Sant Antoni lodgings remained open (Cirer 2004; Planells 1984; Ramón 2001). Possibly this difference is due to various authorities in Sant Antoni who managed to reduce the repressive action of the militiamen and the corresponding response from the other side. This marked a first difference in favor of Sant Antoni that would have returns in later years (Ramón and Serra 2013c). The 1940s were the worst of the century: poverty and ration cards for residents; years lost for tourism due to the war and postwar situation in Spain and Europe; and climatic events such as the 1941 drought, which aggravated the situation. They were also the worst years of the Franco Regime in terms of repression: carnival was forbidden; bathing on the beaches was separated by sex; there was reluctance to tolerate the arrival of foreigners; among other things (Ramón 2001). All the testimonies, both documents and interviewees, corroborate how bad that decade was.

The attitude of the Franco Regime towards foreign visitors in the 1940s was due to two elements. In the first place, there was fear of infiltration by spies from other countries and, as in other non-belligerent European countries, the fear of an invasion was constant. For this reason, photographing coasts or armed forces (barracks, equipment and personnel) was forbidden and border controls were meticulous. Second, conservative national-Catholic morality was at its peak, and concern about the risk of a copycat effect among the local population led to strict control of foreigners. Fortunately, over the years, hostile opinions were replaced by enthusiastic support, especially when the regime authorities became aware of the significant inflow of foreign exchange that international tourism implied (Ramón 2001). It should be noted that the Franco Regime began a process of reforms starting in 1950 that some historians consider a first antecedent of the democratic transition carried out in the 1970s. In any case, these changes increased the freedoms and well-being of people under the Regime.

At the end of the 1940s, there were some small signs of hope for tourism: in 1945 a regatta was organized between Barcelona and Sant Antoni; in 1947, the regular BarcelonaIbiza line reappeared, essential for residents and tourists (Ramón 2001); and in 1949, the application of some norms was relaxed through instructions to civil governors (Cirer 2004). Thanks to these small changes, some Spanish tourists began to arrive in 1947. Moreover, there was a hopeful change in 1950, at the end of the United Nations (UN) embargo and the ration cards (Ramón 2001).

For Sant Antoni businessmen, the year 1950 was the beginning of tourism when the first organized group arrived, specifically French from the Argonauts Club (Planells 1980). 
The French were the main nationality, more than $25 \%$ of the total, until the opening of the aerodrome to commercial traffic in 1958 (Soriano 1996), when the English gained prominence (Cirer 2004). The first groups of English arrived in Sant Antoni in 1952 and the first groups of Germans in 1954. In reality, tourism was distributed among several nationalities, transmitting a cosmopolitan image: "If Ibiza has ever been Babel—as many reports that used this image claim-it was then, that is, in the late 1950s and early 1960s" (Planells 2002, p. 40).

In 1950, there were three hotels and four inns in Sant Antoni, with a total of 114 rooms and 206 beds, already being the nucleus with the most beds (42.8\%) and overnight stays (51.9\%) on the island. The leadership of Vila in 1935 is replaced by the leadership of Sant Antoni and this will continue until the end of the 1960s, when there are already many areas of the island with important tourist developments. The possible reasons for the leadership of Sant Antoni in the 1950s and 1960s are of two types: privileged natural environment, and very tolerant political-social situation.

Sant Antoni was a small town facing south, located near the beach in the great bay of Portmany. All this made it possible to offer visitors a combination of a small coastal town, beaches with calm waters and Mediterranean nature, ideal for holiday tourism in the second half of the 20th century. Despite the enormous urban growth, the bay has preserved many highly attractive areas, such as Cala Bassa and Platges de Comte (Cala Conta), two beaches that retain an appearance similar to that of decades ago. Two regular island tourists, Roy and Margaret Taylor, describe the already heavily urbanized 1970s bay in the following words:

"The bay of Sant Antoni was so placid that you could see how the herons moved from one end of the bay to the other. To get to the beaches that were furthest from the tourist establishments, you had to go in small boats that crossed picturesque places and crossed charming beaches: Port des Torrent, Cala Comte, Cala Gració. Every day we enjoyed a new adventure. At night, the smell that came from the pines was superimposed on the sound of the cicadas. [ ... ] In the years when Sant Antoni was as small as a town, it was already beginning to stand out as a city, to adapt to the notable increase in the number of tourists, but it was still a charming place to visit" (Ramón 2001, p. 232).

Another important and differentiating element of the urban nucleus of Sant Antoni was the political and social aspect. Ibiza was far from the power centers of Palma and Madrid:

"Ibiza was very far from Madrid, and had few communications with the satrapy of Palma de Mallorca, where the civil governor and provincial head of the Movement resided" (de Castro 2003, p. 173).

In addition, it was not seen by the Franco Regime as a conflictive region, since the Ibizan population was mostly conservative and quite apolitical. The militants opposed to the regime being scarce and not very active. In the case of Sant Antoni, this was even more pronounced: it was far from the authorities of Madrid, Palma and Vila; the events that occurred during the war left the town quite apart from repressive actions by both sides (Ramón and Serra 2013c); and the little militancy left was concentrated in Vila, being minimal in the rural area. The moral and political norms of the regime governed the people, as in the rest of the country, but their effective application was very lax. Antoni Planells Ferrer, manager of the Ibiza Hotel (formerly Great Hotel) from 1950 to 1958, commented:

"Society dancing and night clubs were forbidden on the island of Ibiza, while in San Antonio people danced every night on the terrace of a cafe, near the town hall. Nor were the ladies bothered by their way of dressing, and nothing happened. Or rather, if it happened with many clients of our [Ibiza] hotel who had gone on an excursion to San Antonio, some asked for the bill and went to that town because there was a 'beach'" (Planells 1984, pp. 276-79). 
During the early 1950s, visitor numbers were similar to those prior to the Spanish Civil War (Cirer 2004; Planells 1984)—very insufficient to have a significant impact on the island's economy - but growth was significant from 1955 with the new summer sea routes. New hotels were built in Sant Antoni, such as the Bahía Hotel (with central heating, garden and swimming pool), and others were expanded, such as the Ses Salines Hotel (which went from 15 to 135 rooms). Both examples were the work of Rafael Marino Llácer, one of the pioneers of the 1930s. The result was that in 1960 there were 10 hotels and 13 inns with 2007 beds in Sant Antoni (Cirer 2004; Planells 1984; Ramón 2001), which implies 10 times the 1950 capacity.

In the early years, the demand for workforce was covered by people from the town, but very soon it began to attract young people from increasingly remote rural areas of the island. This situation excited the local population, as the sculptor Antonio Hormigo Escandell commented: "Very soon progress came and we loved that many hotels were built, because Sant Antoni was growing" (Planells 1980, p. 187). However, the foreigners who arrived looking for a quiet place to reside had another attitude, as Hans Hinterreiter comments:

"In 1953 I was scared by inflation. San Antonio was already inaugurating the era of tourism. I saw that the first hotels were being built in the bay and I needed another corner [to live]" (Planells 1986, p. 121).

Starting in the mid-1950s, Sant Antoni became the economic capital of the island, concentrating between half and two-thirds of the island accommodation supply (Cirer 2001, 2004) and almost monopolizing the growth in accommodation supply and tourists (Buades 2004). In Sant Antoni they joked that now you don't "go down to Vila", you "go up to Vila", as a symbol of the exchange of roles between Vila and Sant Antoni, according to one of the interviewees. The journalist Fernando-Guillermo de Castro commented that, it the late 1950s, "San Antonio was the tourist capital of the island, without prejudice to the city and Santa Eulària" (de Castro 2003, p. 33). At the beginning of the 1960s, young people from all over the island worked during the summer months in the Sant Antoni companies because there was more jobs and they earned more than in the island's capital. As a consequence of its primacy in the sector, it was also the entry point for the latest in leisure and consumer products. For example, the first fireworks on the island, in the late 1950s, were for the Sant Bartomeu festivities (August 24) held in Sant Antoni, according to one of the interviewees. Another example were the town shops, which sold products that were previously unknown or unusual among the resident population, but commonly consumed by foreign tourists, as another of the interviewees commented.

Despite the spectacular growth rates, the truth is that the data were still low for the island as a whole. According to various authors (Cirer 2004; Ramón 2001), in the early 1950s fewer than 5000 visitors came to an island with 35,312 inhabitants and in 1960 a little more than 42,000 visitors came to an island with 34,339 inhabitants. Although in 1960 tourism was already the island's main source of foreign exchange (Cirer 2004; Ramón 2001), it was far from being sufficient to sustain an acceptable quality of life for residents, especially when the primary sector was in clear decline. The result is that the island of Ibiza lost $2.4 \%$ of its population in the 1950s. The municipality of Sant Antoni, despite concentrating a large part of the tourist activity of that time, lost $4.0 \%$ of the population in the 1950s. It should be noted that, outside the urban nucleus of Sant Antoni, the municipality (with $126.7 \mathrm{~km}^{2}$ of extension) was still rural, poor and inland. Even today, the municipality of Sant Antoni has very different realities in its different towns and areas.

In the 1960s, the growth of the sector continued at high speed and in 1970 there were more than 360,000 visitors on the island (Cirer 2004; Ramón 2001), eight and a half times the figure of 1960 . The sector grew so much that already the local population was not enough to cover the jobs, and workers began to arrive from the south of the Iberian Peninsula, especially from towns in the interior of Andalusia and Extremadura (Rodríguez 2003). Some stayed on the island only during the summer months and others ended up permanently residing in Ibiza. The result is that the population of the Pityuses grew $22.2 \%$ in the $1960 \mathrm{~s}$, but it was an irregular growth. Sant Joan lost $34.2 \%$ of its 
population, while Sant Antoni gained $52.9 \%$ and Vila gained $45.5 \%$. This gives an idea of the uneven development that existed on the island.

The municipality of Sant Antoni in fact has very few beaches (Cala Gració, Cala Salada and El Arenal in the bay, and several tiny coves) and the entire southern part of the bay of Portmany, including the best beaches, belongs to the municipality of Sant Josep de Sa Talaia. Therefore, very soon the new hotel openings spread across the south of the bay along an area of Sant Josep currently known as Cala de Bou. Around 1970, many hotels in the bay of Portmany were in the Sant Josep part, although Sant Antoni was still the central urban nucleus of the area.

Other areas of the island began to develop tourism very quickly following a very similar process. The municipality of Ibiza/Eivissa only has two and a half beaches (Talamanca, Ses Figueretes and part of Platja d'en Bossa). Once the Ses Figueretes area was urbanized, the hotel expansion continued in Platja d'en Bossa, starting in the part closest to Vila and continuing towards the salt flats. In the second half of the 1960s the hotel development of Platja d'en Bossa already reached the part of Sant Josep. Later, in the 1970s there was a rapid development of tourism in Santa Eulària and Formentera and in the 1980s in various areas of Sant Josep not bordering Sant Antoni or Vila. It should be noted that Sant Josep concentrates most of the best beaches and coves on the island: Cala Bassa, Cala Carbó, Cala Comte, Cala d'Hort, Cala Jondal, Cala Molí, Cala Tarida, Cala Vadella, Es Cavallet, Platja de Ses Salines, Platja d'en Bossa, Port d'es Torrent, among others.

The rapid growth of the sector was due to the economic and social improvements that took place throughout Western Europe, the tourist issuing market of the Mediterranean destinations of that time and the improvements in Ibiza's infrastructure. Entering and leaving the island were costly for tourists and a bottleneck that limits the volume of arrivals; therefore, its improvement allows it to continue growing. During the second half of the 20th century, tourists traveled mainly by plane, even more to island destinations, and the airport was a key infrastructure for a destination like Ibiza. When the Es Codolar airport opened in 1958, it was little more than a dirt runway with a house that served as a terminal (Ramón 2001), but many improvements were made during the following years: paving, expansion and marking of the runway; and a newer, more spacious and complete terminal, etc. As a result, as of 1964 the Ibiza airport was able to operate normally, although international flights could not land at the airport until customs was cleared in 1966 and the airport acquired international status (Cirer 2004). With the opening of the airport to international traffic, mass tourism hired by tour operators began to arrive in large volumes, as they did not have to make a stopover in Mallorca for customs procedures (Ramón 2001), starting the tourist boom in the late 1960s (Ramón and Serra 2013a).

In Sant Antoni, the available local workforce was no longer sufficient to attend the tourist season and it was necessary to start with important hiring of external workers in 1965. They came from the inland towns of the south of the Peninsula and were a very important volume until the start of agrarian subsidies in the 1980s, reducing the incentive to emigrate. So many people came to the town of Sant Antoni from La Puebla de Cazalla, located in the province of Seville (Andalusia), that some say that half of La Puebla is in Sant Antoni-a comment made by an interviewee from La Puebla. The vast majority of the workers had no prior training, starting as apprentices and completing their training with informal or self-taught courses, and the working conditions were very harsh, as Elsa Alonso (UGT) commented:

"The workers were housed in the basements of the hotels, in large rooms, in deplorable hygienic conditions. Logically, women and men were separated and married couples could not coexist" (Ramón 2001, p. 119).

In the 1960s, the tourist sector of Sant Antoni lost relative weight, but it was because many other areas of Ibiza began an explosive development, copying Sant Antoni in some cases and learning from their mistakes in others. An example of the weight of Sant Antoni in Ibiza tourism is that the island's main road artery is the Vila-Sant Antoni Road and the Vila ring road that runs from this road to the airport. 
The final years of the 1960s were characterized by a disorderly and very rapid growth of the tourist offer, a spectacular increase in the arrivals of tourists and seasonal workers and a national and international media impact of Ibiza that made it known internationally (Ramón and Serra 2014a). For this reason, the final years of the 1960s and the beginning of the 1970s are known as the years of the Tourist Boom. The media impact of that time was due to the presence of people from the counterculture, especially hippies from Western Europe and North America (Ramón 2001; Rozenberg 1990).

The lack of professionalism, experience and planning during the first years of tourism development generated enormous growth, but with serious deficiencies that caused problems starting in the 1980s, especially in pioneering areas such as the town of Sant Antoni and the Ses Figueretes area. In the case of Sant Antoni, these problems are exemplified in the town center, in the West End area of bars and nightclubs and in the obsolescence of many hotels located within the urban nucleus. This has meant that for the last forty years the town of Sant Antoni has focused almost exclusively on young and low-budget British tourism (Ferrer 2016).

\section{Workers and Businessmen in Sant Antoni}

Although there was tourism before the Spanish Civil War, it was small and ignored by a lot of the population (Ramón and Serra 2014c). It was in the 1950s that there arose indications of significant interest and involvement of residents in the tourism sector (Ramón 2017b). This interest was due to the terrible years of the war and the postwar period, with the 1940s leaving an indelible mark on those who lived them, as the testimony of Enrique Ramón Fajarnés shows:

"The time of real hunger, not fictitious, was still near. It is true that the 1940s were terrible, not only because of hunger, but also because of fear. The fear continued even in the 1950s, fear of going back, to the situation before. For this reason, when tourism began to generate wealth, there were people who said: 'If this stops, there won't be enough trees for those who will have to hang themselves'" (Diario de Ibiza, 8 February 2010).

It must be borne in mind that the young people of the 1950s had lived through the war in their childhood and the postwar period in their adolescence, and those of the 1960s a postwar childhood and adolescence not much better. The fear that Enrique Ramón mentions, the illusions mentioned by Antonio Hormigo and the figures of that time show that, in the 1950s, tourism was more a potential solution than current solution. They were on the right track, but it was still insufficient to guarantee a way out of poverty. However, there was not only a desire to improve economically and get away from the "years of misery"; there was also a desire for knowledge, freedom, leisure and social exchange. The result was a combination of landscape and customs that evoked what Xavier Rubert de Ventós called the Mediterranean as a cultural myth (Rubert 2003), and a very important tolerance and predisposition to foreigners. This combination was commented on by the hotelier Vicent Juan Guasch:

"[In Ibiza] there was a real desire to exchange cultures, customs, languages. At that time, Ibiza offered a typicality, a tranquility, a hospitality. In summary, the island was an irresistible place, with its people open, tolerant, and with a true irrepressible desire to begin the opening" (Ramón 2001, p. 81).

This was even more true at the heart of tourism development in the 1950s. In Sant Antoni everything was on a small scale, with few residents and few vacationers, and contact was direct and close between everyone. As Fernando-Guillermo de Castro indicated:

"In Sant Antoni you can say that everyone was known and treated. The locals alternated with foreign residents, who were few, and with the usual peninsular vacationers; even with some tourists with whom they mingled in bars and nightclubs" (de Castro 2003, p. 33). 
Tourism development and the collapse of the primary sector reversed the value of the land (Cooper 1974; Rozenberg 1974) and, if we take into account that tourism does not require high levels of knowledge and training, there was a radical change in the social strata of the island (Cooper 1974). It can be indicated that, of the large pre-1950 owners, only the Matutes family has retained a preeminent position in the Ibiza economy after the tourist boom and this is due to the fact that they refocused their businesses towards the tourism sector in the late 1960s. Although there was an important social change, thanks to tourism, it is true that the possession of better training and certain financial capital or properties helped people to prosper in the new sector.

An important characteristic of Ibiza's tourism development is that it was endogenous; that is, with local entrepreneurs who invested a small amount of their own capital or requested financing, usually from tourist intermediaries (Ramón 2001). The poverty of the 1940s generated a desire for improvement that led many tourism workers to start businesses quickly and poorly planned. This generated many management problems in the years to come, but it showed an enterprising and risky mentality on some of the local inhabitants.

The jobs were covered by the local youth as long as possible and subsequently completed with youth from the Peninsula, and many of these workers who arrived from the Peninsula came from areas even poorer than Ibiza. As a result, by 1970 the entrepreneurs were eminently local and the best jobs in the sector were mostly covered by Ibizan workers, with immigrants concentrating on the lowest valued and paid jobs (Cooper 1974). This translates into the poor adaptation of neocolonial interpretations to the case of Ibiza (Cooper 1974), as is the case in other parts of the first world (Boissevain 1996).

The tourist workers of Sant Antoni were initially young people from the town and the adjacent rural areas; later, young people from rural areas and towns increasingly remote were incorporated, until in the 1960s, when workers from outside the island were needed to complete the workforce (Rozenberg 1990). Normally, they entered the sector as soon as they finished their mandatory studies and it was not a complex decision, since the alternative was to work on their small family farm, usually dry land and not very productive. Working on the farm was dirty, lonely, frowned upon and unprofitable compared to tourism. In addition, postwar poverty made working for somebody else desirable, as Enrique Ramón narrated:

"We worked every day of the week, without holidays, of course, and it didn't seem like we were miserable, on the contrary, we considered that we had extraordinary luck. At that time, working hard was happiness. Moonlighting was normal and we accepted all the jobs that came in. In the 1950s and 1960s, the more work we had the happier we were" (Diario de Ibiza, 8 February 2010).

Typically, tourist workers had partial primary or secondary education and no specific training when they started out. Specific training was acquired on the job, as an apprentice or assistant, through informal language courses (often taught by foreigners residing on the island), hospitality or business management books, among others. The dynamic was one of total improvisation and troubleshooting on the go. For example, when groups of French people began to arrive in Sant Antoni in 1950, they quickly looked for French-speaking people who could teach French, and in a similar way it happened in 1952 with English and in 1954 with German, according to some interviewees. Another striking element is that many workers in the sector, especially when people from the Peninsula began to arrive, worked in the winter in hotel construction (bricklayer in winter and waiter or cook in summer), illustrating the lack of labor specialization of that time. At the beginning of tourism there was more enthusiasm and wishful thinking than knowledge and training, resulting in hotel buildings and tourist services that could be improved.

In general, young people who began to work at the age of fourteen, fifteen or sixteen in tourist establishments followed three different life paths: an important group left the sector after a few years to dedicate themselves to other activities, tourism being only a youth job; others continued as employed tourist workers all their lives, usually without changing their professional profile; those most prone to taking risks made the leap to entrepreneurship, 
creating tourist businesses of all kinds. This last group is the origin of the vast majority of the local tourism businessmen.

Although there have been people with knowledge, capacity, resources and intention to undertake in the sector since the 1930s (Cirer 2021a), examples are Juan Villangómez Ferrer with the Great Hotel in Vila (Cirer 2021b) and José Roselló Cardona with the Portmany Hotel in Sant Antoni (Cirer 2017), was an anecdotal minority. In reality, specialized training has always been in short supply. For example, in the Sant Antoni of the 1950s there were half a dozen people with university or equivalent training but only one case in management, Pepe Roselló (personal communication). Josep Roselló Prats studied law and is a business professor, a degree equated with a Diploma in Business Sciences (Infante 2012) and the current university degree in Business Administration. Pepe Roselló is one of the bestknown businessmen due to his more than sixty years of experience creating and managing restaurants like El Refugio and S'Olivar, and bars like El Rincón de Pepe. But he is best known for the nightclubs that he created and managed throughout his life, highlighting Play Boy (opened in 1963) and Play Boy 2 (opened in 1975) in Sant Antoni. However, his most successful project was the Space Ibiza nightclub, located in Platja d'en Bossa, which remained open from 1989 to 2016, being one of the world leaders in nightclubs (Prats 2021). It is difficult to measure the exact importance of his academic training in the business results achieved, but it seems obvious that it helped the success.

Most of the entrepreneurs were people with primary or secondary education, with financing provided by tour operators or loans, and had limited aversion to risk. One of the first examples of this profile was Rafael Marino Llácer, founder of the Ses Savines Hotel and the Bahía Hotel, whose business activity is to this day being continued by his son and his grandson.

The entrepreneurs of that time were young workers in the tourism sector who made the leap to entrepreneurship: in some cases, they failed; in other cases, they created an establishment or small business that afforded them a reasonably good level of income and, in a few cases, they created very relevant business groups on the island, demonstrating exceptional business genius. Of this last group there are examples such as Alonso Mari Calbet and Vicente Juan Guasch, with equivalents outside the island, such as Gabriel Escarrer Julià in Mallorca. Unfortunately, in most cases there were deficiencies in management and, for example, amortizations and commercialization were ignored:

- Amortizations are the imputation of the cost of a multi-year resource to the income statement of the corresponding years and their practical implication is the accumulation of a quantity of economic resources necessary to reform, modernize or renew fundamental infrastructures and equipment for the company. In practice, many entrepreneurs spent all the money available once the bills for the season had been paid, saving nothing for future renovations or contingencies. The main effect of this error was that, in the 1980s, the offer of Sant Antoni was obsolete and deteriorated but there was no financial capacity to solve it, opting for a much less demanding and more conflictive tourism (Ferrer 2016).

- The financing of many hotels was carried out by tour operators in exchange for multiyear contracts for the entire capacity of the hotel and a fixed price. When selling the entire capacity of the hotel for several years, for convenience the distribution and commercialization actions in the tourist source markets were totally ignored, totally delegating this function to the tour operators, until the risk of being totally dependent on the intermediaries was confirmed in the 1990s.

The enormous training deficiencies of businessmen and managers in the sector led to the creation of the School of Tourism in 1965 (Ramón 2001) —an initiative of several businessmen from the island. This school aimed to improve the training of businessmen and managers in the sector, an objective that was partially achieved.

With the tourist development not only a much-needed economic improvement was sought; there was also a search for contact with outsiders and access to knowledge and 
practices of the European societies of that time, in essence to imitate what they imagined the normality of the arriving tourists to the island. Mariano Planells commented:

"Ambitious Ibizans asked for loans to build hotels, while at night and secretly, they learned English and free love, German and business management, French and freedom of thought" (Planells 2002, p. 31).

All the young people involved in the sector combined both aspects, economic and social, but there were two main trends: those who prioritized socializing and enjoying leisure, called palanqueros (Ramón 2021); and those who prioritized a work well done, the truly professional workers.

The palanqueros are not an exclusive profile of Ibiza (Fuentes 2017), but within Ibiza it is strongly linked to the Sant Antoni of the 1950s and the beginning of tourism. The palanqueros were young people who worked in the tourism sector and interacted with tourists both at work and outside of it (Ramón 2021). They frequented bars and tried to engage in conversations or flirt with foreign women. It is the realization of the myth of "Don Juan and the Swedish" that became popular during the years of the Spanish tourism boom (Nash 2015, 2018). Antoni Hormigo commented:

"Our first relationships with tourists used to be limited to making an appearance in Can Tarba. That was the birth of the palanqueros, an expression that became famous years later. [...] From what I remember, the first tourists were middleaged, with young women in their forties and younger women..." (Planells 1980, p. 185).

In reality, under this label, widely used in the 1950s and 1960s, there are very different situations. In most cases the behavior was reduced to frequenting a tourist bar and engaging in conversation with female tourists, with no other intentions. In some cases, it could be considered a failure due to exaggerated expectations (Fuentes 2017; Galán et al. 1977) with female tourists for whom they were only nice boys (Nash 2018); but, in other cases there were no more claims for any of the parties, being gallantry without ulterior motives. In these cases, the word palanquero is a bit exaggerated.

A minority group, this one very deserving of the term "palanquero", was characterized by its similarities with the idea of masculinity that Hugh Hefner's Playboy magazine began to spread in those years. These authentic palanqueros could be defined as a playboy adapted to the social and historical context of Sant Antoni in the 1950s and 1960s: they were daring and with enough sexual conquests, and they dressed elegantly according to the canons of the island at that time; they were of humble origin, but, thanks to tourism, they had medium-high incomes that they consumed in leisure and ostentation, habitually going to trendy nightspots and traveling to exotic tourist destinations (Ramón 2021).

Although this profile has not completely disappeared and there are always people who try to replicate what they consider to be the Ibizan lifestyle, especially newcomers with an unrealistic idea of the tourism sector, its golden age was at the beginning of vacation tourism; that is, in the Sant Antoni of the 1950s and 1960s. In reality, the palanqueros were a consequence of the inexperience and lack of professionalism of those years, not having assumed that tourism was an economic activity that required workers and businessmen with ethics and preparation. Many palanqueros spent money at the same rate as they entered it and at the end of the season, they had not saved anything, leading them to abandon the sector and the life of excesses. This profile was made up of both workers and employers, with bankruptcies being very frequent in the latter case, and the palanquero has remained a common reference to the 1950s and 1960s in Sant Antoni, but in a highly mythologized and idealized way. However, over the years, another more "professional" profile dominated the sector (Ramón 2021).

"Professional" workers and businessmen do not despise the leisure and social contact that tourism allows, but they are aware that they are doing serious work and consider the palanquero unsustainable in economic, social, psychological and health terms. In terms of behavior, they differ little from workers and businessmen in non-tourist regions and, in 
reality, they are more averse to excesses than people without contact with tourism, having seen the consequences closely. They constitute an overwhelming majority among veteran workers and businessmen from tourist regions. In the case of Ibiza, this profile increased as time progressed, and their knowledge is consolidated in the tourism sector.

\section{Conclusions}

Tourism workers and businessmen of the 1950s and 1960s sought to enjoy what they lacked in a childhood lived in critical times, the palanqueros being the most extreme result of the clash between young people from the Ibizan countryside and some cosmopolitan and adventurous tourists, both in the work context and in leisure. These were years of improvisation and very rapid growth that formed a different local identity, with positive and negative elements, which has reached the present day unfailingly linked to the idea of Ibiza.

It is worth mentioning here some aspects of the mentality and way of doing of the local population. Since before tourism development there has been a tendency to prioritize networks of "friendships" and favors over direct procedures and adjusting to regulations, something that surprises foreign researchers (e.g., Cooper 1974). This implies a predisposition to solve multiple issues (e.g., bureaucratic procedures, job search, etc.) through these networks and not in a transparent way and adjusted to the regulations, with this behavior still being very common today. The desire to progress after the years of poverty, the lack of training and the low qualifications necessary to work in tourism generated a desire for "easy money" and a tendency to moonlight in poorly paid and poorly performed jobs, spending the money earned quite "easily" in travel and leisure (imitating the palanqueros). This search for easy profit and the usual irregularities were reinterpreted as freedom and tolerance in the imagination of sporadic visitors. In general, these local peculiarities generated positive elements (entrepreneurial and risky mentality, tolerance for newcomers, image of freedom, etc.) and negative elements (failures in business management, abundance of irregularities in multiple legal aspects, improvisation and lack of planning, etc.) that have come to the present.

The freedom and tolerance mentioned by visitors from the 1950s has become the backbone of tourism and the image of the island for seventy years. This freedom is translated into elements that range from the island's macro-nightclubs to the way to dress (Ramón 2016) or behavior in public spaces. A taste for travel and leisure has also remained in local society that is higher than usual in other regions of the country and, sometimes, greater than its economic capabilities. In addition, in relation to nightlife, they are demanding and difficult to surprise, since for them the offer of Ibiza is normal and not the exceptionality that it represents for the rest of the world.

The main deficiencies of the 1950s were the lack of business culture of the entrepreneurs and the lack of professionalism of the workers. An example of a lack of training and professionalism was the lack of long-term vision of the businessmen, implying a weak reinvestment and the obsolescence of the offer, whose most important effects were noticed from the 1980s with a degraded offer and a demand based on conflictive British tourism, and the urban center of Sant Antoni being a paradigm of this.

Unfortunately, seventy years later many of these deficiencies continue to occur and there is still something of the mentality of the palanqueros among part of the local population: hotel renovations are still carried out in a hurry and with deficiencies, as in the times of the boom of the 1960s; the preparation of workers, employers and society in general has improved but remains insufficient; improvisation and lack of long-term planning is very common; the taste for leisure and travel characterizes many young and old; and the level of spending of many residents is beyond their means; among other things. The island needs to think on its future in view of the past and what happens in the leading and competing destinations, but if it continues as it does today, there may be a significant economic and social crisis in the future, due to inertia from the past. 
On the social front, the tourist development of Sant Antoni in the 1950s and 1960s was the center of an unprecedented transformation of the island and its society. The children of families that subsisted on small family farms became a new middle class of employed workers and small entrepreneurs. As for local businessmen, many of them originate from young people of that time who decided to jump into entrepreneurship, with most of the island's tourism companies remaining in local hands until very recent times. However, in recent years, many tourism companies have been sold to investment funds and companies from outside the island due to problems of generational change or lack of financing for reinvestments.

This article is an approach to an era mythologized by many people and for different reasons, but it would be useful to go deeper while there are direct testimonies. It is local history and tourism history, but it is also a case study of how a society reacts to rapid and radical changes. Therefore, an analysis of the before (1940s), during (1950s and 1960s) and after (1970s and 1980s) the origin of tourism in Sant Antoni would be of interest. In general, the history of tourism in Ibiza, the social and economic changes it caused, and the present of the sector is a field of study that still has a long academic journey.

Author Contributions: Conceptualization, J.R.-C. and M.D.S.-F.; investigation, J.R.-C.; writingoriginal draft preparation, J.R.-C.; writing—review and editing, M.D.S.-F.; supervision, M.D.S.-F. All authors have read and agreed to the published version of the manuscript.

Funding: This research received no external funding.

Institutional Review Board Statement: Not applicable.

Informed Consent Statement: Informed consent was obtained from all subjects involved in the study.

Data Availability Statement: Not applicable.

Conflicts of Interest: The authors declare no conflict of interest.

\section{References}

Alarco, Claudio. 1978. Kultur und persönlichkeit auf Ibiza. Doctoral dissertation, University of Cologne, Cologne, Germany.

Azpelicueta, $\mathrm{M}^{\mathrm{a}}$ Carmen, José Ramón, and Antoni Serra. 2015. Mythical references in the tourist image: The case of Ibiza. European Journal of Tourism, Hospitality and Recreation 6: 39-55.

Benjamin, Walter. 2008. Cartas de la época de Ibiza. Valencia: Editorial Pre-textos.

Berrozpe, Arturo. 2016. Ibiza como marca de destino turístico. Opción: Revista de Ciencias Humanas y Sociales 32: 111-20.

Berrozpe, Arturo, Sara Campo, and María J. Yagüe. 2017. Understanding the identity of Ibiza, Spain. Journal of Travel E Tourism Marketing 34: 1033-46.

Boissevain, Jeremy (Ed.). 1996. Coping with Tourists: European Reactions to Mass Tourism. Oxford: Berghahn Books.

Buades, Joan. 2004. On Brilla el Sol. Turisme a Balears abans del Boom. Eivissa: Res Pública Edicions.

Butler, Richard W. 1980. The concept of a tourist area cycle of evolution: Implications for the management of resources. The Canadian Geographer 24: 5-12. [CrossRef]

Cirer, Joan Carles. 2001. Evolució de l'oferta de places turístiques a Eivissa i Formentera (1950-2000). Estudis sobre turisme a Eivissa $i$ Formentera 2: 73-93.

Cirer, Joan Carles. 2004. De la fonda a l'hotel. La Gènesi d'una Economia Turística. Palma: Edicions Documenta Balear.

Cirer, Felip. 2017. L'hotel Portmany: La utopia d'un antonienc. Josep Roselló Cardona. Eivissa: Editorial Mediterrània-Eivissa.

Cirer, Joan Carles. 2021a. Economic and social resilience accounts for the recovery of Ibiza's tourism sector. Tourism Geographies 23: 479-500. [CrossRef]

Cirer, Joan Carles. 2021b. The stunning birth of tourism on the islands of Ibiza and Formentera. Island Studies Journal 16: 323-40. [CrossRef]

Cirlot, Juan Eduardo. 2021. Diccionario de Símbolos. Madrid: Ediciones Siruela.

Cooper, Ronald J. 1974. An analysis of some aspects of social change and adaptation to tourism on Ibiza. Doctoral dissertation, Oxford University, Oxford, UK.

de Castro, Fernando-Guillermo. 2003. La isla perdida. Memoria de una época de Ibiza. Eivissa: Editorial Mediterrània-Eivissa.

Ferrer, Joan Lluís. 2016. Viaje al turismo basura. Barcelona: Editorial UOC.

Ferrer, Joan Lluís (Coord.). 2019. Història d'Eivissa i Formentera: Des de la prehistòria fins al turisme de masses. Eivissa: Balàfia Postals.

Fuentes, Alicia. 2017. The Spanish Latin lover: A strictly domestic myth? A visual inquiry about the role of eroticism in Spanish tourism imaginaries (1950-70). Via: Tourism Review, 11-12. [CrossRef] 
Galán, Juan José, Angel Martín, Josefina Ruiz, and Antonio Mandly. 1977. Costa del Sol. Retrato de unos colonizados. Madrid: Campo Abierto Ediciones.

Gil, Carlos. 1970. Juventud Marginada. Estudio sobre los "Hippies" a su paso por Formentera. Barcelona: Editorial Dopesa.

Gil, Carlos. 1971. Formentera una comunidad en evolución. Barcelona: Editorial Dopesa.

INE. 2021. Censos de Población. Madrid: Instituto Nacional de Estadística.

Infante, Jorge. 2012. La Ley General de Educación (1970) y la integración de los estudios de comercio en la universidad española: Del verde mar al naranja. Cuadernos del Instituto Antonio de Nebrija 15: 11-41.

Michaud, Yves. 2012. Ibiza Mon Amour: Enquête sur l'industrialisation du plaisir. Paris: Nil editions.

Nash, Mary. 2015. Mass tourism and new representations of gender in late Francoist Spain: The Sueca and Don Juan in the 1960s. Cultural History 4: 136-61. [CrossRef]

Nash, Mary. 2018. Masculinidades vacacionales y veraniegas: El Rodríguez y el donjuán en el turismo de masas. Rubrica Contemporánea 7: 23-39. [CrossRef]

Nieto, José Antonio. 1977. Estudio antropológico económico de una comunidad: El caso de Formentera. Doctoral dissertation, Complutense University of Madrid, Madrid, Spain.

Nikolakakis, Michalis. 2015. Representations and social practices of alternative tourists in post-war Greece to the end of the Greek Military Junta. Journal of Tourism History 7: 5-17. [CrossRef]

Parrón, Artur. 2000. La Guerra Civil a Eivissa i Formentera. Palma: Edicions Documenta Balear.

Paul, Elliot. 1937. Life and Death of a Spanish Town. New York: Ramdom House.

Pizza, Antonio. 2016. Experiencias y pobreza en el Mediterráneo: Walter Benjamin, Raoul Hausmann, Erwin Broner (Ibiza, años 30). In Arquitectura importada y exportada en España y Portugal (1925-1975). Coordinated by José Manuel Pozo, Héctor García-Diego and Beatriz Caballero. Pamplona: T6 Ediciones, pp. 53-64.

Planells, Mariano. 1980. Ibiza, la senda de los elefantes, volumen I. Palma: Antigua Imprenta Soler.

Planells, Antonio. 1984. Ibiza y Formentera, ayer y hoy. Barcelona: Antonio Planells Ferrer.

Planells, Mariano. 1986. Ibiza, la senda de los elefantes, volumen II. Barcelona: Ediciones Obelisco.

Planells, Mariano. 2002. El nacimiento de Babel -Ibiza años 60-. Eivissa: José Ferrer y Vicent Guillamó.

Prats, Xescu. 2021. Pepe Roselló. La Ibiza Vivida. Eivissa: Balàfia Postals.

Ramón, Ernesto. 2001. Historia del turismo en Ibiza y Formentera. 1900-2000. Eivissa: Genial Ediciones Culturals.

Ramón, José. 2016. Moda Adlib: De los hippies a los turistas. International Journal of Scientific Management and Tourism 2: 177-206.

Ramón, José. 2017a. Consolidación de Ibiza como destino turístico (finales del siglo XX). Gran Tour: Revista de Investigaciones Turísticas 16: $43-62$.

Ramón, José. 2017b. La Guerra Civil Española y la implicación de los residentes en el turismo: El caso de Ibiza. Revista Iberoamericana de Turismo (RITUR) 7: 86-104.

Ramón, José. 2017c. Peculiaridades del turismo de Formentera. International Journal of Scientific Management and Tourism 3: 555-78.

Ramón, José. 2021. 'Palanqueros' a Sant Antoni de Portmany. Contacte turístic i identitats de classe entre els treballadors locals (1950-1970). In Cultura turística i identitats múltiples a les Illes Balears. Passat i Present. Edited by Antoni Vives Riera and Francesc Vicens Vidal. Catarroja: Editorial Afers, pp. 195-222.

Ramón, José, and Antoni Serra. 2013a. Historia social del desarrollo turístico en Ibiza (décadas de 1960 y 1970). Análisis desde perspectivas historiográficas. Investigaciones Turísticas 5: 86-109.

Ramón, José, and Antoni Serra. 2013b. Simbiosis entre realidad e imagen en un destino turístico. Revista Académica Hologramática 18: $3-22$.

Ramón, José, and Antoni Serra. 2013c. Tolerancia y desarrollo turístico: Sant Antoni en los años cincuenta. CULTUR: Revista de Cultura e Turismo 7: 132-56.

Ramón, José, and Antoni Serra. 2014a. Elementos de la contracultura de los años sesenta en la oferta turística de un destino maduro. Revista Iberoamericana de Turismo (RITUR) 4: 110-24.

Ramón, José, and Antoni Serra. 2014b. Historia del turismo en Ibiza: Aplicación del Ciclo de Vida del Destino Turístico en un destino maduro del Mediterráneo. PASOS: Revista de Turismo y Patrimonio Cultural 12: 899-913. [CrossRef]

Ramón, José, and Antoni Serra. 2014c. Inicios del turismo y actitudes de los residentes: El caso de Ibiza (España). Estudios y Perspectivas en Turismo 23: 1-22.

Robertson, Alexander F. 1965. The sunshine revolution: The impact of the tourist industry on a peasant community. Geographical Magazine 37: 926-39.

Rodríguez, Rosa. 2003. Avantguarda artística i societat a Eivissa (1933-1985). Eivissa: Res Pública Edicions.

Rozenberg, Danielle. 1974. San Miquel, village ibicenco. Traditions culturelles et développement touristique (étude ethnographique). Doctoral dissertation, Faculté des Lettres et Sciences Humaines de Paris, Paris, France.

Rozenberg, Danielle. 1990. Ibiza, una isla para otra vida: Inmigrantes utópicos, turismo y cambio cultural. Madrid: Centro de Investigaciones Sociológicas.

Rubert, Xavier. 2003. Del Mediterráneo como mito cultural. DC PAPERS: Revista de Crítica y Teoría de la Arquitectura 9/10: 17-28.

Soriano, Francisco. 1996. Pequeña historia del turismo en las Baleares. Palma: Editorial Bitzoc.

Takeuchi, Keiichi, and Hisako Kurihara. 1979. Peripheral tourism-A case study in Ibiza. Hitotsubashi Journal of Social Studies 11: 31-52.

Valero, Vicente. 2001. Experiencia y Pobreza: Walter Benjamin en Ibiza, 1932-1933. Barcelona: Edicions Península. 
Valero, Vicente. 2004. Viajeros Contemporáneos: Ibiza, siglo XX. Valencia: Editorial Pre-textos.

Vives, Sònia, and Onofre Rullan. 2020. La urbanización de la pobreza: De la acumulación originaria a la crisis habitacional en Ibiza. Boletín de la Asociación de Geógrafos Españoles 87: 1-44.

Vuillier, Gaston. 1893. Les îles oubliées. Les Baléares, la Corse et la Sardaigne. Impressions de voyage illustrées par l'auteur. Paris: Librairie Hachette et Cie.

Yin, Robert K. 2017. Case Study Research and Applications. Design and Methods, 6th ed. Thousand Oaks: Sage Publications. 